\title{
ONKO TERMILLÄ VÄLIÄ?
}

\section{PÄÄKIRJOITUS}

RIITTA

SEPPÄNEN-JÄRVELÄ
Kun kohta kymmenisen vuotta sitten siirryin kuntoutuksen kentälle sosiaalipalveluiden arvioinnin alueelta, muistan vieroksuneeni termiä 'kuntoutuja'. Omaksuin kuitenkin käsitteen nopeasti ja opin sitä sujuvasti käyttämään. Ajoittain kuitenkin havahdun pohtimaan käsitteen merkitystä.

Kielen ja puheen merkitys on suuri; sanat ja niihin liittyvät merkitykset ja mielleyhtymät ohjaavat ajattelua ja tekoja. Tämän vuoksi ei ole yhdentekevää, mitä käsitteittä käytetään, kun tarkoitus on puhua kuntoutuspalveluita käyttävästä ihmisestä.

Kuntoutuspalveluihin osallistuvat ihmiset eivät välttämättä koe itseään kuntoutujiksi - kuntoutustakin saatetaan pitää vieraana terminä. Esimerkiksi työllistymistä edistävää ammatillista kuntoutusta koskeneessa tutkimuksessa tuotiin esille, että termit kuntoutuja ja kuntoutus ovat työnantajan näkökulmasta hankalia tai jopa harhaanjohtavia. Tutkimuksen mukaan työnantajat eivät välttämättä tiedä, pitäisikö henkilölle tarjottavien työtehtävien tai työolojen olla jollain tavoin erityisen kuntouttavia. Toisaalta kuntoutukseen osallistuneet ihmiset toivat esille, että kuntoutujan rooli oli tarjonnut heille suojaa ja antanut tarvittavaa etäisyyttä työn ja työyhteisön vaatimuksiin. Kuntoutujan rooli saatettiin siis kokea myönteisellä tavalla suojaavaksi, tai siihen saatettiin ottaa myös kriittisesti etäisyyttä. (Haapakoski ym. 2020.)

Toisaalta nuorten näkökulmasta termi 'kuntoutus' voi herättää mielikuvan vakavista terveydellisistä ongelmista. Kelan NUOTTI-valmennus onkin esimerkki uudentyyppisestä kuntoutuspalvelun nimeämisestä, jonka toivotaan puhuttelevan paremmin kohderyhmänsä nuoria.

Perinteisesti sosiaalipalveluiden käyttäjää on kutsuttu asiakkaaksi. Myös terveydenhuollossa on ollut ajoittain näkemyksiä, että potilas on asiakas. Asiakas-termikään ei ole arvovapaa ja neutraali vaan voi viedä ajatukset kohti liiketoimintaa tai myyntiä ja markkinointia. Toisaalta asiakas-termiin liittyy tietty dynaaminen toimijuus - aktiivinen asiakas tekee valintoja ja käyttää palveluita.

Kaisa Karppinen (2018) selvitti opinnäytteessään, kuinka potilasja asiakas-sanojen käyttö julkis- ja yksityissektorilla eroaa toisistaan. Hän havaitsi, että asiakkaan osallistumista sanoitettiin julkissektorin aineistossa selvästi enemmän kuin yksityissektorilla. Asiakkaan osallistumiseen sisältyy osallisuus kuntoutuksen suunnitteluun ja 
päätöksentekoon sekä luonnollisesti itse kuntoutustoimintaan. Asiakas- ja asiakkuusnäkökulmasta kuntoutus muodostuu erilaisista kasvokkain tai sähköisesti tapahtuvista - tavoitteellisista kohtaamisista. Niissä osallistujat vaihtavat keskenään voimavaroja, tunteita, tietoja tai tekoja. Asiakkuudessa ollaan aina suhteessa johonkin.

Tämä Kuntoutus-lehden numero on oivallinen esimerkki kuntoutuksen ja kuntoutumisen moninaisesta maailmasta; sekä tieteelliset artikkelit että puheenvuorot tuovat esille alueen monisävyisyyden ja rikkauden. Keskeiset käsitteet ja termit tarkentuvat ja saavat lisää sisältöä.

Tässä lehdessä tieteelliset artikkelit ovat luonteeltaan integroivia kirjallisuuskatsauksia. Niissä liikutaan laajasti kuntoutuksen kentällä: ammatillisen kuntoutuksen, tutkimusmaailman ja sähköisten mielenterveyspalveluiden alueella. Tutkijaryhmä Krista Lehtonen, Nea Vänskä, Sari Helenius, Toini Harra ja Salla Sipari tarkastelee osallistuvaa tutkimuskumppanuutta. Kumppanuus näyttäytyy monin eri tavoin, mutta keskeinen havainto kuitenkin on se, että aito kumppanuus edellyttäisi kulttuurin muutosta tutkimustoiminnassa. Toinen kirjallisuuskatsaus käsittelee työnantajayhteistyötä ammatillisessa kuntoutuksessa ja tuetussa työllistymisessä. Leena Åkerblad ja Kaisa Haapakoski kirjoittavat erityisesti siitä, millainen työnantajayhteistyö on osoittautunut toimivaksi ja miten yhteistyösuhdetta rakennetaan ja ylläpidetään. Kolmannessa, Mari Kivistön kirjoittamassa artikkelissa fokus on sähköisissä mielenterveyspalveluissa, erityisesti toipumisen näkökulmasta. Hän toteaa, että integroiva kirjallisuuskatsaus voi auttaa jäsentämään aihealuetta käsitteellisesti; katsauksessa toipumisen käsite jaoteltiin kolmeen alateemaan: kliiniseen toipumiseen, henkilökohtaiseen toipumiseen ja osallisuuden vahvistumiseen.

Matias Lahden kirjoittama puheenvuoro sotainvalidien sairaskotien historiasta palauttaa mieleen suomalaisen kuntoutustoiminnan lähtökohtia ja asioita, jotka määrittävät yhä myös nykyistä kuntoutuspalveluiden kenttää. Hilla Sumanen puolestaan summeeraa kokemuksia pelastajien ja ensihoitajien post-traumatyöpajasta. Hän peräänkuuluttaa keinoja henkisen hyvinvoinnin vahvistamiseen ja psyykkisen kuorman purkamiseen traumatisoivissa työtehtävissä.

\section{Kohisten kohti digiä!}

Kuntoutus-lehti on ajassa kiinni - vuoden 2021 alusta lehti alkaa ilmestyä verkkojulkaisuna. Julkaisijat Kuntoutussäätiö ja Kuntoutusalan tutkimus- ja kehittämisyhdistys Kutke ry päättivät kuluvan vuoden syyskuussa, että nyt on viimein aika - muiden tiede- ja ammattilehtien tavoin - tehdä merkittävä siirtymä painetusta sanasta kohti digitaalista julkaisemista. Näin siis Kuntoutus-lehti alkaa ilmestyä yksinomaan verkkojulkaisuna kotimaisten tiedelehtien Journal. fi-palvelussa, jota ylläpitää Tieteellisten seurain valtuuskunta.

Miksi verkkojulkaisu? Siirtymää pohdittiin pitkään ja läpikotaisin. Tärkeitä seikkoja on tarjota lukijoille moderni ja laadukas julkaisu, jonka ajanmukaisuus myös houkuttelee tieteellisten tekstien kirjoittajia. Tavoite on tarjota käyttäjäystävällinen, ekologisesti kestävä rat- 
kaisu; vanhoja lehtiä ei tarvitse säilöä hyllyssä, vaan artikkelit ovat helposti löydettävissä ja saatavissa Journal.fi-palvelusta. Ajatus on, että sähköinen lehtiarkisto palvelee tehokkaasti tiedonhakijaa ja on käytettävissä missä ja milloin vain erilaisilla laitteilla.

Tilaajamaksut säilyvät ennallaan lukuun ottamatta uutta tilaajaryhmää, yhteisötilaajia. Lehden tilaajat saavat lukuoikeuden erillisen maksukoodin kautta verkkolehden uusien numeroiden artikkeleihin. Muille verkkolehti avautuu vapaasti luettavaksi vuoden kuluttua ilmestymisestään. Sisällysluettelo, pääkirjoitukset sekä tieteellisten artikkeleiden ja katsausten ja analyysien tiivistelmät ovat avoimesti luettavissa heti. Lehden vanhoja numeroita lisätään Journal.fi:n arkistoon vähitellen.

Riitta Seppänen-Järvelä

päätoimittaja, Kelan tutkimus

\section{Lähteet}

Haapakoski K, Åkerblad L, Tolvanen A, Mäntysaari M (2020) Kelan työllistymistä edistävä kuntoutus. Palvelun toimivuuden edellytykset. Sosiaali- ja terveysturvan raportteja 22, Kela, Helsinki.

Karppinen K (2018) Potilas- ja asiakas-sanojen käyttö terveydenhuollon organisaatioiden verkkosivuilla. Semanttisia rooleja, tyypillisiä piirteitä ja vertailua. Pro gradu -tutkielma. Hoitotieteen ja terveyshallintotieteen tutkimusyksikkö, terveyshallintotiede, Oulun yliopisto. Saatavissa: http://jultika.oulu.fi/files/ nbnfioulu-201806022422.pdf 